https://mri.lipi.go.id

Marine Research in Indonesia

e-ISSN: 2443-2008

p-ISSN: 0216-2873

Original Research Articles

\title{
Variation of temperature and zeolite application on simulated transport of cultured juvenile sea cucumber (Holotburia scabra)
}

\author{
Ida Ayu Amarilia Dewi Murni ${ }^{1 *}$, Muhammad Firdaus ${ }^{2}$, Lisa Fajar Indriana ${ }^{2}$, Marenda Pandu Rizqi ${ }^{1}$ \\ ${ }^{1}$ Bitung Marine-Life Conservation Unit, Indonesian Institute of Science (LIPI) \\ ${ }^{2}$ Division for Marine Bio Industry, Indonesian Institute of Science (LIPI)
}

\begin{abstract}
ARTICLE INFO
Article history:

Submitted 9 September 2020

Revised 7 September 2021

Accepted 12 September 2021

Published online 30 Oktober 2021

Keywords:

sea cucumber juvenile

transportation

temperature

zeolite

survival rate

\section{ABSTRACT}

Sea cucumber (Holothuria scabra) aquaculture practice requires different sites for the juvenile and grow-out phases. While broodstock conditioning, spawning, and the nursery phase are mostly done in an indoor hatchery, the juvenile must be raised in saltwater ponds, sea pens, or ex-situ grow-out sites. However, information on optimal transport conditions with regard to post-transport survival from the hatchery to the grow-out sites is limited. This gap in of knowledge required immediate research since the demand for sustainable sea cucumber culture is constantly increasing, whether for commercial or conservation (restocking) purposes. Therefore, the aim of this study is to investigate the effectiveness of transportation methods for juvenile sandfish by combining temperature and zeolite treatment. The variation of temperature (low and ambient) combined with the use of zeolite treatment on the simulated transport condition of sea cucumber juveniles were evaluated in this study. This experiment used 3 (three) replicate groups consisting of 10 (ten) individual hatchery-produced sea cucumber juveniles (less than $0.1 \mathrm{~g}$ weight) held in 4 (four) different treatments of temperature and zeolite addition to medium water for the 12 hour duration of simulated transport. The monitoring result of water quality ( $\mathrm{pH}$ and ammonia) and the survival rate of sea cucumber juveniles observed within 7 (seven) days post-transport suggests that $\mathrm{pH}$ and survival rate were affected by the temperature regime and zeolite addition. The addition of zeolite and the increase of temperature tend to decrease $\mathrm{pH}$ values. However, excessive temperature decrease should be avoided during the transportation process as it tends to reduce the survival rate of sea cucumber juveniles.
\end{abstract}

(C2021 Indonesian Institute of Sciences (LIPI)

\section{Introduction}

Indonesia has been a major supplier of sea cucumber products worldwide, especially for markets in Singapore, China, Korea, Japan, the United States, and several countries in Europe. It provides $40-80 \%$ of total demand in Hong Kong (Conand and Tuwo, 1996; Ferdouse, 2004). The export volume of Indonesian sea cucumber in 2012 was $905,233 \mathrm{~kg}$, which was valued at USD 4,613,120 (Kementerian Kelautan Perikanan, 2012). One of the most exploited high-value sea cucumber species is sea cucumber (Holothuria scabra, locally known as "teripang pasir") (Eriksson et al., 2012; Indriana et al., 2017; Militz et al., 2018; Robinson, 2013). Continuous exploitation without proper stock management will likely cause overfishing and a decreasing sea cucumber population in their natural habitat (Purcell and Kirby, 2006). In the long term, overfishing might affect their reproduction cycles, which would slow their natural recovery process. The solution to this problem can be achieved through the development of aquaculture technology to rear sea cucumbers within their natural habitat (Robinson and Lovatelli, 2015). Aquaculture produced sea cucumber can be used for commercial purposes to meet the market demand, and has recently been used in the conservation effort, for instance in restocking activities (Indriana et al., 2017; Rizqi, 2018)
The grow-out phase of sea cucumber aquaculture is mostly conducted in separate sites/facilities from its initial phases. The broodstock conditioning, spawning, and nursery phases were conducted in a controllable environment of a hatchery, while the grow-out phase was conducted outdoors in ponds, sea pens, or protected coasts, which can be located far from the hatchery (Agudo, 2006). In commercial aquaculture or conservation efforts of sea cucumber, the quality of juveniles is one of the factors influencing the positive result, where unhealthy and unfit juveniles tend to be difficult to adapt the new environment. Thus, it may increase post-transport mortality due to stress-induced conditions and increase the risk of predation. The quality of juveniles that will be used in restocking is also influenced by genetic factors, hatchery management, and transport methods (Purcell et al., 2006). Robinson and Pascal (2012) studied that stressful conditions during juvenile transport are one of the potential causes of high mortality during their initial release to new sites.

Several studies related to transport methods of sea cucumber juveniles have been conducted. Purcell et al. (2006) studied the transport method of $H$. scabra. While Zamora and Jeffs (2015) investigated the transportation method of 
Table 1. Summary of experiments in transportation simulation of sea cucumber Holothuria scabra juveniles

\begin{tabular}{lllll}
\hline & CZ & CNZ & AZ & ANZ \\
\hline Temperature & lower/cold & lower/cold & ambient & ambient \\
\hline Medium & seawater + zeolite + ice cubes & seawater + ice cubes & seawater + zeolite & seawater \\
\hline
\end{tabular}

Note: (CZ) cold temperature with zeolite, $(\mathrm{CNZ})$ cold temperature without zeolite, $(\mathrm{AZ})$ ambient temperature with zeolite, (ANZ) ambient temperature without zeolite.

brown sea cucumber (Australostichopus mollis) juveniles. The transportation methods in both studies were applied to juveniles weighing between 1 - 5 grams. For cost-efficiency purposes, the juvenile should be transported at a high density, which consequently leads to a decreased level of dissolved oxygen (DO) and $\mathrm{pH}$, an increased level of ammonium $\left(\mathrm{NH}_{3}\right)$ and carbon dioxide $\left(\mathrm{CO}_{2}\right)$ in the water. This unfavorable water quality may cause additional stress and even mortality if the juveniles are kept in transport conditions for a prolonged period. Due to the aforementioned shortcomings, further study is needed to find alternatives to overcome problems related to juvenile transportation.

Zamora \& Jeffs (2015) experimented with temperature regulation during the transportation process by adding ice cubes to the transport container/box. The result of that study showed that an increase in seawater temperature and an excessive decrease in temperature during transport negatively affected sea-cucumber juveniles. Meanwhile, studies on transportation methods by adding zeolite or active carbon as an $\mathrm{NH}_{3}$ absorber have been conducted in the close transportation system of Giant Gouramy (Osphronemus gouramy) (Nirmala et al., 2012), and Orange-spotted Grouper (Epinephelus coioides) (Cheng et al., 2014). The addition of zeolite in the transport package from these studies decreased ammonia- $\mathrm{N}$ and $\mathrm{CO}_{2}$ levels. Nevertheless, adding zeolite to medium water during the transportation process of sea cucumber juveniles is a novel approach to reduce the toxic impact of ammonium. Moreover, the possibility of transporting the smaller size of sea cucumber juvenile (less than 1 gram) needs to be assessed and evaluated due to its lower transport cost. Therefore, this study aims to investigate the effectiveness of sea cucumber juveniles (Holothuria scabra) transportation methods by combining the addition of zeolite with regulating the water temperature to control water quality during the transportation process.

\section{Materials and Methods}

\subsection{Source of Sea Cucumber Juvenile}

The study was conducted in the Aquaculture Laboratory of the Division for Marine Bio-Industry LIPI (Balai Bio Industri Laut LIPI), North Lombok, Indonesia, in March 2016. Sea cucumber juveniles (Holothuria scabra) (120 individuals, DPH 60 ) were obtained from the hatchery of BBIL LIPI. Random examinations of sea cucumber juveniles were held prior to the experiment to ensure that the juveniles were healthy, active and absent from noticeable diseases. Ten randomly selected juveniles were packed into each plastic bag with biomass of around 0.45 $\pm 0.03 \mathrm{~g}$ (mean value: $0.04 \mathrm{~g}$ ). Prior to the experiment, these plastic bags with juvenile sea cucumbers were placed into a plastic container with $100 \mathrm{~L}$ of filtered seawater and deprived of feeding for 24 hours.

\subsection{Experimental Design}

There were four different experiments, each with three replicates, combining two types of treatments (temperature regime and zeolite addition),i.e.,. lower/cold temperature with zeolite (CZ), lower/cold temperature without zeolite (CNZ), ambient temperature with zeolite (AZ), and ambient temperature without zeolite (ANZ). Ten sea cucumber juveniles weighing $0.04 \mathrm{~g}$ each were put into a plastic bag containing $250 \mathrm{ml}$ of seawater and $750 \mathrm{~mL}$ pure oxygen gas. On the zeolite treatment (CZ and AZ), 5 (five) grams of natural zeolite were wrapped inside cloth bandages and packed together with medium water inside plastic bags. The lower temperatures were achieved with the addition of $1000 \mathrm{~g}$ of ice cubes inside the styrofoam box $(55 \mathrm{~L} \mathrm{vol})$ containing the experiment plastic bags (CZ and CNZ). While the ambient temperature groups ( $A Z$ and ANZ) were held inside another similar sized styrofoam box without the addition of an ice cube (Table 1 ).

In order to simulate transportation, the styrofoam boxes containing sea cucumber juvenile were held for 12 hours on top of static orbital shakers (Amtast SKL180). The temperature was measured by placing two $\mathrm{Hg}$ thermometers inside the experimental plastic bags. Hourly visual temperature observations were conducted directly through the plastic bags without opening the styrofoam box and removing the thermometers to avoid the risks of inaccurate temperature measurement affected by ambient temperature. Water quality measurements, including $\mathrm{pH}$ and TAN (Total Ammonia Nitrogen), were performed electrochemically at the start and end of the simulation (12 hour period) using a $\mathrm{pH}$ meter (Hanna HI 98107) and the APHA method (Eaton et al., 2005).. In the end of the simulation, the juveniles were counted and placed in separate $10 \mathrm{~L}$ tanks. The groups of juveniles were then reared separately for 7 (seven) days to stimulate the adaptation period needed during actual transport to grow-out sites. During the 7 days post-simulation, the juveniles were fed concentrated seagrass (Enhalus acoroides) juice ad libitum. Water treatment during this period includes aeration and 50\% daily water exchange. The survival rate of juveniles in each tank was monitored twice daily.

\subsection{Statistical Analyses}

All collected data was organized using MS Excel 2010 (Microsoft Corporation) and analysed in the RStudio application version 1.1.463. Prior to analysis, Shapiro-Wilk's test was used to test the normality of the data, and Levene's test was used to test the equality of the data variance (homogeneity). The effect of treatments (temperature and zeolite) on variables including survival rate and $\mathrm{pH}$ was analysed using a two-way ANOVA test with equal replication in RStudio. Meanwhile, the effect of treatments on the ammonia level was tested using Two-Way ANOVA without replication in MS Excel 2010 since there was only one data for each treatment. 


\section{Results}

\subsection{Water Quality}

Based on the observation, the result suggests that there were significant differences in the water $\mathrm{pH}$ level between treatments with zeolite and without zeolite $\left(\mathrm{F}_{(1,8)}=54.898, \mathrm{p}<0.001\right)$. Moreover, the significant differences also occurred between the lower and ambient temperatures $\left(\mathrm{F}_{1,8}=40.333, \mathrm{p}<0.001\right)$. Nevertheless, there was no significant interaction between the temperature and zeolite treatment on the $\mathrm{pH}$ level of medium water during transportation simulation. Figure 1a showed that the $\mathrm{pH}$ of water from treatment without zeolite (CNZ \& ANZ) was higher than treatment with zeolite (CZ \& AZ). Additionally, within similar zeolite treatment, the $\mathrm{pH}$ of medium water from lower temperature treatment groups (CZ and CNZ) were higher than that of ambient temperature groups (AZ and ANZ). Figure $1 \mathrm{~b}$ showed that the ammonia level (TAN) from non-zeolite treatments (CNZ \& ANZ) was higher than groups with zeolite treatments (AZ \& CZ). The highest TAN level occurred in groups without zeolite at ambient temperature (ANZ), which was $0.058 \mathrm{mg} / \mathrm{L}$. However, there was no significant difference in TAN level between temperature treatments $\left(\mathrm{F}_{(1,3)}=0.55, \mathrm{P}=0.59\right)$ and zeolite treatments $(\mathrm{F}(1,3)=2.03, \mathrm{P}=0.38)$.

The observation results of the hourly temperature measurement of medium water in temperature treatment groups during 12 hours of simulated transport showed $+/-2^{\circ} \mathrm{C}$ fluctuation in ambient groups ( $\mathrm{AZ}$ and ANZ), between $26^{\circ}$ and $28^{\circ} \mathrm{C}$ (Figure 2). In contrast, the temperature declined significantly during 12 hours, from $26^{\circ}$ to $18^{\circ} \mathrm{C}$ in the experiments with lower temperatures (CZ and CNZ) (Fig. 2).

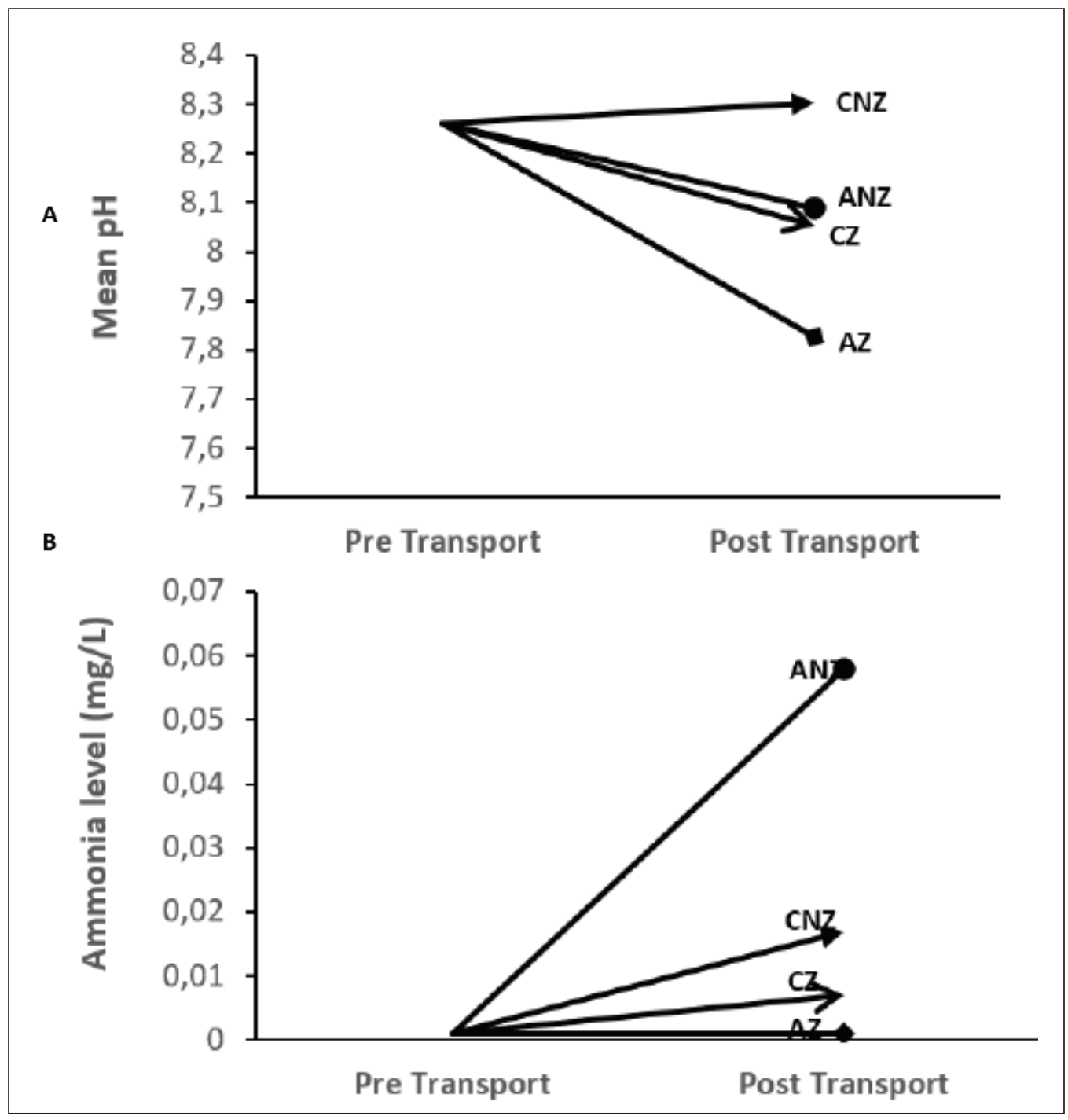

Figure 1. The comparison of $\mathrm{pH}$ level (A); and ammonia level (B) of seawater samples extracted from the plastic bags with sea cucumber juveniles held in seawater at cold temperature with zeolite (CZ), cold temperarture without zeolite (CNZ), ambient temperature with zeolite (AZ), ambient temperature without zeolite (ANZ) between pre- and post-simulated transport. 


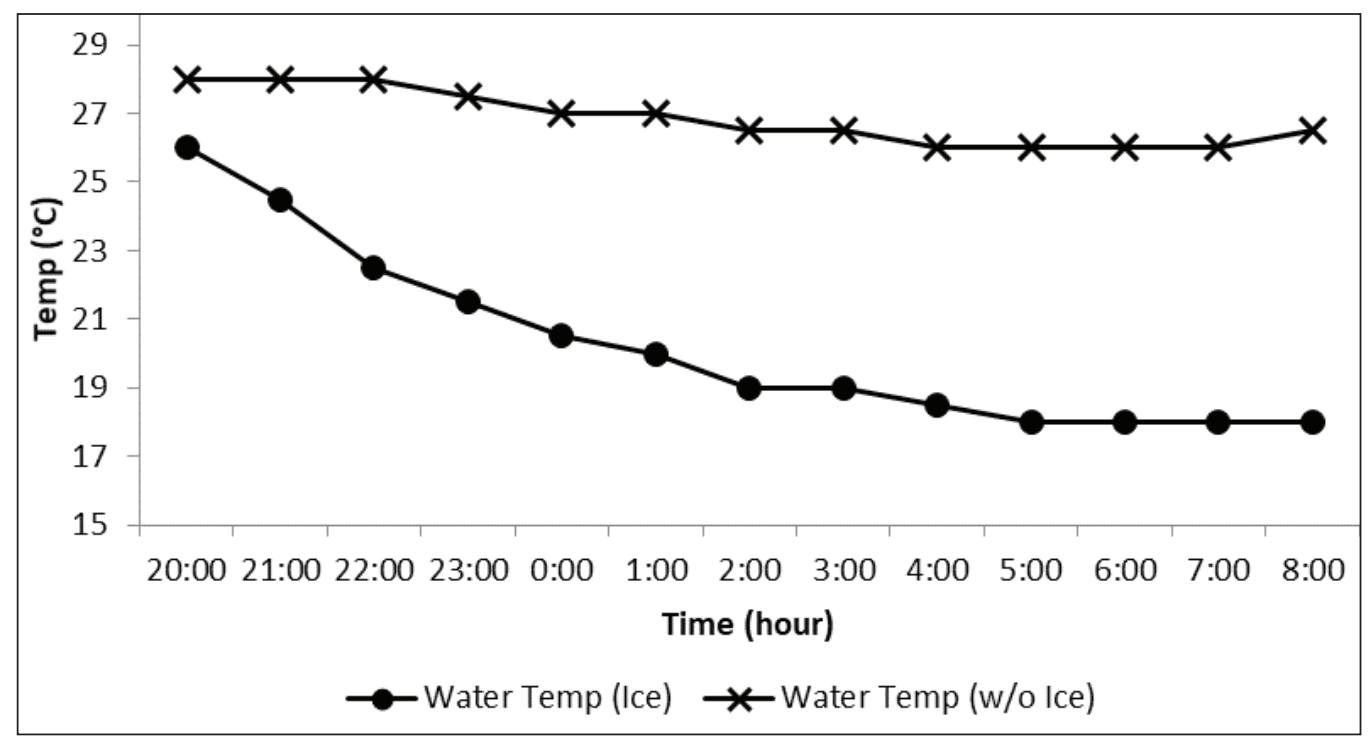

Figure 2. The fluctuation of water temperature during transportation simulation.

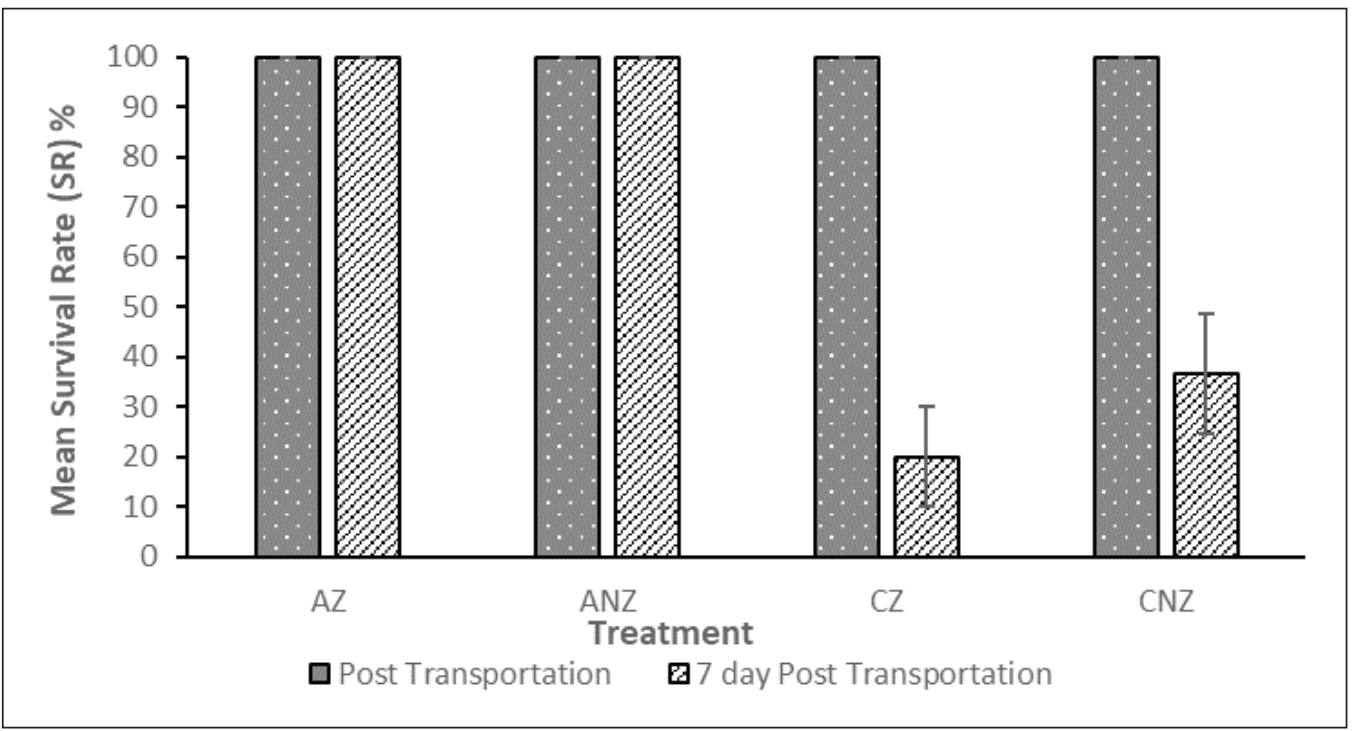

Figure 3. Changes of the survival rate (SR) of juvenile $H$. scabra post and 7 days post transportation.

\subsection{Survival Rate}

Sea cucumber juveniles in all treatment groups have survived survived (SR 100\%) during 12 hours of simulated transport. However, on day 7 post-transport rearing in the tank, mortalities occurred particularly from the lower temperature groups (CZ and $\mathrm{CNZ}$ ). In the end of the experiment (day 7 post-transport), the survival rate of $\mathrm{CNZ}$ and $\mathrm{CZ}$ were $36.67 \%$ and $20 \%$, respectively. In contrast, the survival rate of both $\mathrm{AZ}$ and $\mathrm{ANZ}$ groups were $100 \%$ (Fig. 3).

The result of statistical analysis showed that there were no significant differences in the survival rate (SR) of the sea cucumbers between the zeolite and non-zeolite treatment groups $\left(\mathrm{F}_{(1,8)}=1.136, \mathrm{p}=0.318\right)$. However, there were significant differences in SR between temperature treatment groups $\left(F_{(1,8)}=84.045, p<0.001\right)$. Contrarily, there was no significant interaction of temperature and zeolite treatment on the survival rate of juvenile sea cucumber during transportation $\mathrm{F}_{(1.8)}=1.136$, $\mathrm{p}=0.318$ ).

\section{Discussion}

In adult sea cucumbers, prolonged transport periods may induce evisceration, particularly in high density packing and unregulated temperatures (Tuwo et al., 2019). In sea cucumber juveniles, appropriate transport conditions result in favorable physiological and behavioral responses, which determine their survival success (Zamora and Jeffs, 2015). An increase in water temperature can be lethal for sea cucumber juveniles. It can increase the metabolism and oxygen consumption of sea cucumber juvenile, decrease the feeding activity, and reduce the growth rates (Maxwell and Gardner, 2018). However, based on the results of this experiment, an excessive decrease in temperature during transportation could also be harmful to the juvenile sea cucumber. The survival rate of the juveniles in low temperature treatment groups ( $\mathrm{CZ}$ and $\mathrm{CNZ}$ ) was very low. These conditions might induce juveniles' shock and stress responses to excessive and sudden temperature decreases during the simulated transport process. Similar findings were 
found in a study conducted by Zamora and Jeffs (2015), who discovered that after more than four hours of being exposed to low temperature $(20 \mathrm{oC})$, Australostichopus mollis juvenile eviscerated, stopped feeding and moving, and eventually died. This situation occurred due to their inability to return themselves to their initial condition prior to the transportation process. Conversely, juveniles in 'ambient' temperature treatment groups (AZ and ANZ) were able to recover from the stressed condition due to less temperature fluctuation during transportation, which means that sea cucumber juveniles were likely capable of tolerating such conditions. According to Tonn et al. (2016), the recovery was indicated by decreasing antioxidant enzyme activity and cellular respiration, increasing energy reserves, and increasing cellular energy reserves of the sea cucumber. Temperatures ranging from 22 to $25^{\circ} \mathrm{C}$ ware suitable for the transportation of juvenile sea cucumbers (Purcell et al., 2006). An excessive and quick degradation of temperature while using ice packs during transportation can be prevented by wrapping frozen water bottle in paper, fabric, or other materials to prevent it from direct contact with the animal or transport media. In answering the optimum temperature and transport period length, further study can focus on a longer transport period (more than 12 hour period) with indirect ice pack addition to regulate the temperature during the transport period to be less than $25^{\circ} \mathrm{C}$ while preventing the temperature from being lower than $22^{\circ} \mathrm{C}$.

In relation to the effect of water quality on the survival rate of marine organisms in transportation conditions, $\mathrm{pH}$ value plays a vital role because most marine organisms are unable to tolerate a wide range of environmental $\mathrm{pH}$. According to Boyd (2013), the optimum $\mathrm{pH}$ for marine organisms is 7.5-8.5. The results from this study showed that $\mathrm{pH}$ tends to decrease during transportation simulation. However, the $\mathrm{pH}$ of the water in treatments with zeolite was lower than in treatments without zeolite. The use of natural zeolite in seawater, which contains a high sodium ion concentration, can reduce the $\mathrm{pH}$ value. Wang et al. (2012) stated that the natural zeolite adsorbs the $\mathrm{Na}^{+}$, which is confirmed by lower $\mathrm{pH}$ values at ambient temperature treatment (AZ) compared to low temperature treatment (CZ). This result was also consistent with Le Châtelier's Principle, which states that $\mathrm{pH}$ decreases as temperature rises. In general, under low $\mathrm{pH}$ conditions, there is an increase in mucus production, which can interfere with the respiratory efficiency of the aquatic organism (Boyd, 2013). However, the changes in $\mathrm{pH}$ during transport simulation in this study occurred in the optimum range, which may indicate the possibility of further study on prolonged transport periods or lower volumes of medium water for more efficient space and cost.

During the transportation process, the increased ammonia level in transportation media was linearly related to increased metabolic activity and oxygen consumption. Treatments without zeolite had a higher ammonia level compared to treatments with zeolite. The highest ammonia level was found in groups held at ambient temperature without zeolite treatment. This condition tends to have an adverse effect on sea cucumber juvenile during the transportation process. Regulating temperature plays an important role. At lower temperatures, the metabolic activity of sea cucumber juveniles tends to decrease, which implied that there was a decline in excretion rate due to lower oxygen consumption. Consequently, the ammonia concentration in medium water was also at a low level. It impled that low ammonia can reduce the stress level of juveniles during the transportation process (Estudillo and Duray, 2003).

The use of zeolite has several advantages related to water quality maintenance, particularly a lower ammonia concentration in seawater (Burgess et al., 2004). As confirmed in this study, the addition of zeolite can reduce the increased levels of ammonia in water or medium during the transportation process, even maintaining ammonia at a similar level to initial water quality prior to the sea cucumber juvenile introduction into transport containers. Furthermore, lowering ammonia concentrations in medium water during transport reduces the risk of viral and bacterial pathogen proliferation in groupers (Cheng et al., 2014).

The transport method for sea cucumber juveniles might be a small part in a short period of time compared to the whole cycle of sea cucumber aquaculture. However, a successful transport method, including the length of transport, temperature regulation, ammonia regulation, packing density, and sea cucumber size should be carefully considered as an integrated part of successful sea cucumber culture, particularly when the grow-out sites are distanced apart from its hatcheries. A successful transport method would warrant better juvenile adaptation and survival in grow-out sites. When the initial adaptation period in the grow-out sites has passed, the growth rate of sea cucumber can be as high as $14 \mathrm{~g}$ per month, and up to $300 \mathrm{~g}$ in one year when the environmental conditions are optimal (Agudo, 2006).

\section{Conclusion}

The simulated transport experiment of sea cucumber juveniles suggests that transport for an individual weighing less than $0.1 \mathrm{~g}$ without lowering the water temperature during a 12-hour period in a closed transportation system was feasible. The optimum range of temperature was $26-28^{\circ} \mathrm{C}$ in order to obtain $100 \%$ survival on 7 (seven) days post-transport. The addition of zeolite could help to maintain TAN during the transportation of sea cucumber juveniles and reduce stress caused by an increase in ammonia levels.

\section{Acknowledgements}

This study was fully funded by the Government of Indonesia (GOI) through the thematic research scheme (DIPA) of Bitung Marine-life Conservation Unit (BMCU-LIPI): The Development and Recovery of Sea cucumber Stock in their Natural Habitat (2014-2016). The authors would like to thank Dr. Sigit A.P. Dwiono, Hendra Munandar, Mochtar and the staff of Marine Bio Industry LIPI for their help during the as well as the two anonymous reviewers for their comments and suggestions. All authors contributed equally to this article

\section{References}

Burgess, R. M., Perron, M.M., Cantwell, M.G., Ho, K.T., Serbst, J. R., and Pelletier, M.C. (2004). Use of zeolite for removing ammonia and ammonia-caused toxicity in marine toxicity identification evaluations. Springer, 47(4), 440-447. https://.org/10.1007/ s00244-004-4003-3.

Cheng, A., Lee, C., Chen, Y., and Chen, J. (2014). The effect of packing on water quality parameters, survival and NNV load of Epinephelus coioides fry after simulated transport. Journal of 
Aquaculture Research E'Development, 05(06), 1-5. https://doi. org/10.4172/2155-9546.1000264.

Conand, C., and A. Tuwo, A. (1996). Commercial holothurians in South Sulawesi, Indonesia. fisheries and mariculture. SPC Beche-de-mer Information Bulletin 8:17-21.

Eaton, A. D., L.S. Clesceri, E.W. Rice, A.E. Greenberg, and M. Franson (2005). APHA: Centennial Edition., APHA, AWWA, WEF, Washington, DC.

Eriksson, H., Robinson, G., Slater, M.J., and Troell, M. (2012). Sea cucumber aquaculture in the western Indian Ocean:challenges for sustainable livelihood and stock improvement. AMBIO: $A$ Journal of the Human Environment, (2), 109-121. https://doi. org/10.1007/s13280-011-0195-8.

Estudillo, C. B., and Duray, M. N. (2003). Transport of hatchery-reared and wild grouper larvae, Epinephelus sp. Aquaculture,(1-4), 279-290. https://doi.org/10.1016/S0044-8486(02)00413-1.

Ferdouse, F. (2004). World markets and trade flows of sea cucmber/ beche-de-mer. FAO Fisheries and Aquaculture Technical Paper, 101-118.http://www.fao.org/tempref/docrep/fao/007/ y5501e/y5501e09.pdf

Indriana, L. F., Firdaus, M., Supono, and Munandar, H. (2017). Survival rate and growth of juvenile sandfish (Holotburia scabra) in various rearing conditions. Marine Research in Indonesia, 42(1), 11.https://doi.org/10.14203/mri.v41i2.156.

Kementerian Kelautan Perikanan. (2012). Statistik Ekspor Hasil Perikanan Menurut Komoditi, Provinsi Dan Pelabuhan Asal Ekspor. Jakarta: KKP.

Maxwell, K., \& Gardner, J.P.A. (2018). The effect of diet on the energy budget of the brown sea cucumber, Stichopus mollis (Hutton) reefs tomorrow initiative view project Mōtū kahawai fishery view project. Wiley Online Library,(2), 157-170. https://doi. org/10.1111/j.1749-7345.2009.00239.x.

Militz, T. A., Leini, E., Duy, N.D.Q., and Southgate, P.C. (2018). Successful large-scale hatchery culture of sand fish (Holotburia scabra) using micro-algae concentrates as a larval food source. Aquaculture Reports, 9 (December 2017), 25-30.https://doi. org/10.1016/j.aqrep.2017.11.005.

Nirmala, K., Hadiroseyani, Y., and Widiasto, R.P. (2012). Penambahan garam dalam air media yang berisi zeolit dan arang aktif pada transportasi sistem tertutup benih ikan gurami Osphronemus gouramy Lac. The addition of salt in the water media containing zeolite and active charcoal on closed system transportation. Jurnal Akuakultur Indonesia,(2), 190-201. https://www. academia.edu/download/42901124/7213-20173-1-PB.pdf

Purcell, S. W., Blockmans, B.F., and Agudo, N. (2006). Transportation methods for restocking of juvenile sea cucumber, Holothuria scabra. Aquaculture, (2-4), 238-244.https://doi.org/10.1016/j. aquaculture.2005.04.078

Purcell, S. W., \& Kirby, D.S. (2006). Restocking the sea cucumber Holothuria scabra: Sizing no-take zones through individualbased movement modelling. Fisheries Research80, 53-61. https://doi.org/10.1016/j.fishres.2006.03.020.
Rizqi, M. P. (2018). Budidaya Teripang Pasir (Holothuria scabra) untuk Konservasi Wilayah Pesisir Sulawesi Utara. In T. Peristiwady, M.T. Lasut, M.P. Rizqi (Eds), Prosiding Seminar Pengelolaan Berkelanjutan Sumberdaya Laut dan Pesisir Sulawesi Utara dan Sekitarnya (58-69). Loka Konservasi Biota Laut Bitung.

Robinson, G. (2013, March). A bright future for sandfish aquaculture. World Aquaculture Society Magazine, (1), 18-24.

Robinson, G., \& Lovatelli, A. (2015). Global sea cucumber fisheries and aquaculture: FAO's inputs over the past few years. FAO Aquaculture Newsletter (FAN), 53, 55-58. Retrieved from http://www.fao.org/3/a-i4504e.pdf

Tonn, N., Novais, S.C., Silva, C.S.E., Morais, H.A., Correia, J.P.S., and Lemos, M,F.L. (2016). Stress responses of the sea cucumber Holothuria forskali during aquaculture handling and transportation. Taylor E Francis, (9), 948-957. https://doi.org /10.1080/17451000.2016.1218030.

Tuwo, A., Yasir, I., Tresnati, J., Aprianto, R., Yanti, A., Bestari, A.D., and Nakajima, M. (2019). Evisceration rate of sandfish Holothuria scabra during transportation. IOP Conference Series: Earth and Environmental Science, 370, 12039. IOP Publishing.https://doi. org/10.1088/1755-1315/370/1/012039.

Wang, X., Ozdemir, O., Hampton, M.A., Nguyen, A.V., and Do, D.D., (2012). The effect of zeolite treatment by acids on sodium adsorption ratio of coal seam gas water. Water Research,16), 5247-5254. doi: https://doi.org/10.1016/j.watres.2012.07.006.

Zamora, L. N., and Jeffs, A.G. (2015). Evaluation of transportation methods of juveniles of the Australasian sea cucumber, Australostichopus mollis. Aquaculture Research,(10), 2431-2442. doi: https://doi.org/10.1111/are.12400.

\section{Declarations}

\section{Funding statement}

This research did not receive any specific grant from funding agencies in the public, commercial, or not-for-profit sectors.

\section{Conflict of interest}

The authors declare no known conflict of financial interest or personal relationships that could have appeared to influence the work reported in this paper.

\section{Additional information}

Reprints and permission information is available at https:// mri.lipi.go.id

Publisher's Note: Indonesian Institute of Sciences remains neutral with regard to jurisdictional claims in published maps and institutional affiliations. 